Vietnam Academy of Science and Technology
Vietnam Journal of Earth Sciences
http://www.vjs.ac.vn/index.php/jse

\title{
Geochemical features of Sakhalin Island mud volcanoes
}

\author{
Shakirov R.B. ${ }^{* 1}$, Sorochinskaja A.V.1, Syrbu N.S.1, Tsoy I.B.1, Nguyen Hoang'2, Le Duc Anh ${ }^{3}$ \\ ${ }^{1}$ V.I. Il'ichev Pacific Oceanological Institute (POI), Far Eastern Branch of Russian Academy of Sciences, \\ Vladivostok, Russia \\ ${ }^{2}$ Institute of Geological Sciences, VAST, Hanoi, Vietnam \\ ${ }^{3}$ Institute of Marine Geology and Geophysics, VAST, Hanoi, Vietnam
}

Received 20 July 2017; Received in revised form 21November 2017; Accepted 28 November 2017

\begin{abstract}
The study, based on a complex geochemical research, found that the composition of the most chemical elements in mud breccia from the Yuzhno-Sakhalinsky (YSMV) and Pugachevsky (PMV) mud volcanoes (Sakhalin Island), the unique phenomena of endogenous defluidization in the Hokkaido-Sakhalin fold system (alpine-type folding), are comparable to Clarke (C) contents of these elements (0.8-1.2 $\times \mathrm{C})$. For Na, $\mathrm{Li}, \mathrm{Zn}$ and $\mathrm{Sn}$, the ratio between the elemental contentsand their Clarke values $\left(\mathrm{C}_{\text {sample }} /\right.$ Clarke value $)$ vary from 1.4 to $5.2 \mathrm{xC}$. But the increased contents of $\mathrm{Na}$ and $\mathrm{Li}$ are due to the ascending endogenous fluid revealed. Study of the mud breccia chemical composition changes in different explosive activity of YSMV under the seismic activity variations allowed to establish that, when the mud-volcanic gryphons are activated against the background of increase in the temperature of the water-mud mixture and the emission of spontaneous gases, the contents of a number of elements (iron, calcium, manganese, rare earth elements, etc.) are decreased. This is explained by the formation of soluble hydrocarbonate complexes. Daginskie gasgeothermal system (DGHS) trace elements depleted ooze samples were compared with YSMV and PMV samples and exposed that the high ratios of $\mathrm{C}_{\text {sample }} /$ Clarke values for the majority of elements do not exceed $0.6 \times \mathrm{C}$. Ooze samples from DGHS having higher elemental contents than Clark contents were observed only for Cd content $(2.2-3.4 \times \mathrm{C})$ and $\mathrm{Pb}(0.7-1.5 \times \mathrm{C})$. Analysis of diatom flora on the DGHS site indicates the existence of an active fluid dynamic system that drains oil and gas bearing complexes. The factors determining the "weighting" of the methane carbon isotope composition in the southern part of Sakhalin Island are the increased seismic activity of deep-seated faults, as well as the presence of intrusions (diabase) and metamorphically altered rocks.
\end{abstract}

Keywords: Sakhalin Island; mud volcano; methane; hydrocarbon gas; element composition; faulting tectonics; seismic activity.

C)2018 Vietnam Academy of Science and Technology

\section{Introduction}

Mud volcanoes are the most interesting and rather rare manifestation of defluidization

"Corresponding author, Email: ren@poi.dvo.ru processes on the Earth's surface. According to oil-gas geologists V.N. Weber, K.P. Kalitsky, V.D. Golubyatnikova and I.M. Gubkin, one of the main forming factors of the mud volcanic process is the hydrocarbon potential of sedimentary basins. According to the literature da- 
ta, mud volcanoes, like other sources of methane, are usually found in areas of deep subsidence, in marginal basins and in subductionzones of continental margins (Luckge et al., 2002), especially under conditions of tectonic compression (Kopf, 2002).

The occurrence of mud volcanoes is associated with the outlet to the surface under the influence of excessive pressure of hydrocarbon gases concentrated at depth. A highpressurized fluid is formed in thick clay strata, as a rule, due to phase transformations of clay minerals in the region of high temperatures and pressures and promotes the breakthrough of mud breccias to the surface through volcanic eruptive channels (Kholodov, 2002; Shnyukov et al., 1992). One of the main factors for the formation of mud volcanoes is faulting (Melnikov and Iliev, 1989; Milkov, 2000).

The bulk of solid outputs is elastic clayish rocks, which are common in the continentoceanic marginal areas. Also, water plays a significant role in the activity of mud volcanoes, such that, firstly, penetrating into voids and pores, it leads to swelling of the rocks, turning them into a viscous mass; and secondly, together with the gas, promotes extrusion of a clay mass with rock fragments onto the surface.

Most of the on-land mud volcanoes are located within the Alpine-Himalayan, Central Asian and Pacific mobile orogenic belts, whereas underwater mud volcanoes occur both along passive and active continental margins (Kholodov, 2002).

By analogy with magmatic volcanoes, mud volcanoes are distinguished by two stages of development: active and passive. The active stage is accompanied by a powerful outlet to the surface of gases and liquids of clay pulps (mud-volcanic or mud breccias). During the passive period (salsas-gryphon), a small amount of gases, coarse dirt and water are released from the gryphons, or the gryphon itself ceases its activity altogether (Kholodov,
2002). Both stages are subdivided by transition stage: "relaxation" after mud volcanoes activation or preparation stage before eruption.

The Sakhalin Region is a unique region of Russia, where there are thick sedimentary strata containing oil and gas deposits, with high seismotectonic activity and surfacial mud volcanoes (Ershov et al., 2011; Melnikov and Iliev, 1989; Melnikov et al., 2008). There are four areas of mud volcanism. Three of them are in the south of the island: YuzhnoSakhalin mud volcano (YSMV), $24 \mathrm{~km}$ northwest of the regional center, Pugachevsky group of mud volcanoes (PMV), about 140 $\mathrm{km}$ north of Yuzhno-Sakhalinsk in the Makarovsky district near Pugachevo and Lesnovsky mud volcano in the Korsakovsky district. In the north of Sakhalin, $30 \mathrm{~km}$ north of Nogliki village, the Daginsky gas geothermal field (DGHS) is located. Within the geothermal field, there are about fifteen water and gas sources that are used for therapeutic and prophylactic purposes (mud baths 'Dagi'). Mud-volcanic manifestations are also noted on the shore of the Gulf of Aniva. Villagers of Vostochny (Terpeniya Bay, Sakhalin Island) recounted their eyewitnesses of the extrusion of clay breccias along the shoreline during a seismo-tectonic activity in August 2006.

The study of the chemical composition of mud volcanic activity products (solid, liquid and gaseous) is one of the main directions of the mud volcanoes study (Fedorov et al., 2012; Shnyukov et al., 1992; Yakubov et al., 1980). In this paper, we present the results of a comprehensive geochemical study of mud volcanoes on Sakhalin Island, including the composition of spontaneous gases, the mineral assemblage of the mud breccia and the distribution characteristics of the wide range of its chemical elements. The main goal of the paper is to reveal the connection of the gas discharge changes, element composition, gas geochemical composition and temperature of 
mud-water mixture in mud volcano gryphons with strong earthquakes in the region.

\section{Initial data}

Gas-geochemical monitoring of mud volcanoes on Sakhalin Island has been carried out since 2001 by employees of the Gas Geochemistry Laboratory of the V.I. Il'ichev Pacific Oceanological Institute, Far Eastern Branch of Russian Academy of Science (POI FEB RAS). Gas was sampled from the main degassing gryphons of Yuzhno-Sakhalinsky and Pugachevsky mud volcanoes and the Daginsky geothermal system. Gas samples were collected in glass bottles by displacement using a saturated solution of $\mathrm{NaCl}$ as a buffer. Samples of recent mud-breccias were also collected.

The Yuzhno-Sakhalinsky mud volcano (YSMV), the largest and most active, has been studied in more detail (Figures 1, 2). It is located in the field of the Bykovsky suite of Upper Cretaceous age, one of the thickest siltstoneargillaceous sequences in Sakhalin (up to 3000 $\mathrm{m})$ and tectonically confined to the submeridional Central-Sakhalin deep fault (Tym-Poronaisk uplift) (Geology of the USSR, 1970). Each eruption changes the relief and contours of the mud field. In August 2001, after a series of seismic shocks with an intensity of 5-7 magnitude, the southern and central groups of YSMV gryphons practically ceased to function, but the mud gryphons in the northern part became active and new gryphons were formed (Astakhov et al., 2002; Melnikov et al., 2008). From the vents of the gryphons, samples of spontaneous gases and breccias were collected during a passive period (Yu-9, Yu-10, Yu-22) as well as under an active period (Yu-9 / 17.08, Yu-10/17.08). The same group of gryphons, which were in a passive state, was tested in 2007 (samples 'Naparnik' and 'A-1') and in 2008 (samples E-21, E-22, E23, E-24, E-25 were provided by V.V. Ershov, IMGG, Yuzhno-Sakhalinsk).

Pugachevsky mud volcano (PMV), the second largest, consists of three mud volca- noes that are close together, including the Main and two small ones termed as Small North and Small South. They are located on a rounded hollow ( 2 by $1.5 \mathrm{~km}$ ), overgrown with forest (Melnikov, 2011). PMV is also confined to the Tym - Poronaisk uplift and the Bykov suite is the host-terrain, likewise for YSMV (Geology of the USSR, 1970). Four samples were selected from the Main Pugachev mud volcano (Figures 1,3 ), in a passive state: 1 in 2001 (P-2/2-01), 2 in 2005, (P-1-05 and P-2-05) and 1 in 2006 (P-06).

The Daghinskaya geothermal system (DGHS), also termed as the Dagin mud volcanic manifestation, (Melnikov and Iliev, 1989) is located on the coast of the Nyisky Gulf within the North-Sakhalin trough (Geology of the USSR, 1970) alongside the Daginsky thermal springs (Figure 1, 4). Thermomineral springs belong to slightly alkaline $(\mathrm{pH}$ $=7.4-7.5$ ), chloride-hydrocarbonate sodium waters. The total mineralization is $2-2.5 \mathrm{~g} / \mathrm{l}$. The water temperature is $30-40^{\circ} \mathrm{C}$ (Yakubov et al., 1980). The hydrological regime of the Gulf is determined by the influence of river flows and the tidal currents. During the day time, there are sharp changes in temperature, salinity and water level. In the DGHS there are no explosive eruptions typical for mud volcanoes and mud breccia field, but there is a flow area of gas-and-mud mass from small craters (1.5 to $3 \mathrm{~m}$ in diameter), which are relatively evenly distributed along the bottom (Figure 4). DGHS is controlled by the Garomaisky fault (Lobodenko, 2010). The observed increased contents of helium (20 ppm) and hydrogen (22 ppm) may indicate the activity and significant deposition depth of the fault (Shakirov et al., 2012). At a relatively small depth, there are highly elastic clay deposits of Neogene age (Gladinkov (Editor), 1998; Zharov et al., 2013). According to the literature, DGHS is also associated with the mud volcanic process (Melnikov and Iliev, 1989). Samples from the DGHS were collected in the vicinity of the Kalmar thermal spring located in the tidal zone, including D-01 in 2001; D-05 in 2005; D-12-1, D- 12-2, D-12-3 and D-12-4 in 2012. 
Shakirov R.B., et al./Vietnam Journal of Earth Sciences 40 (2018)

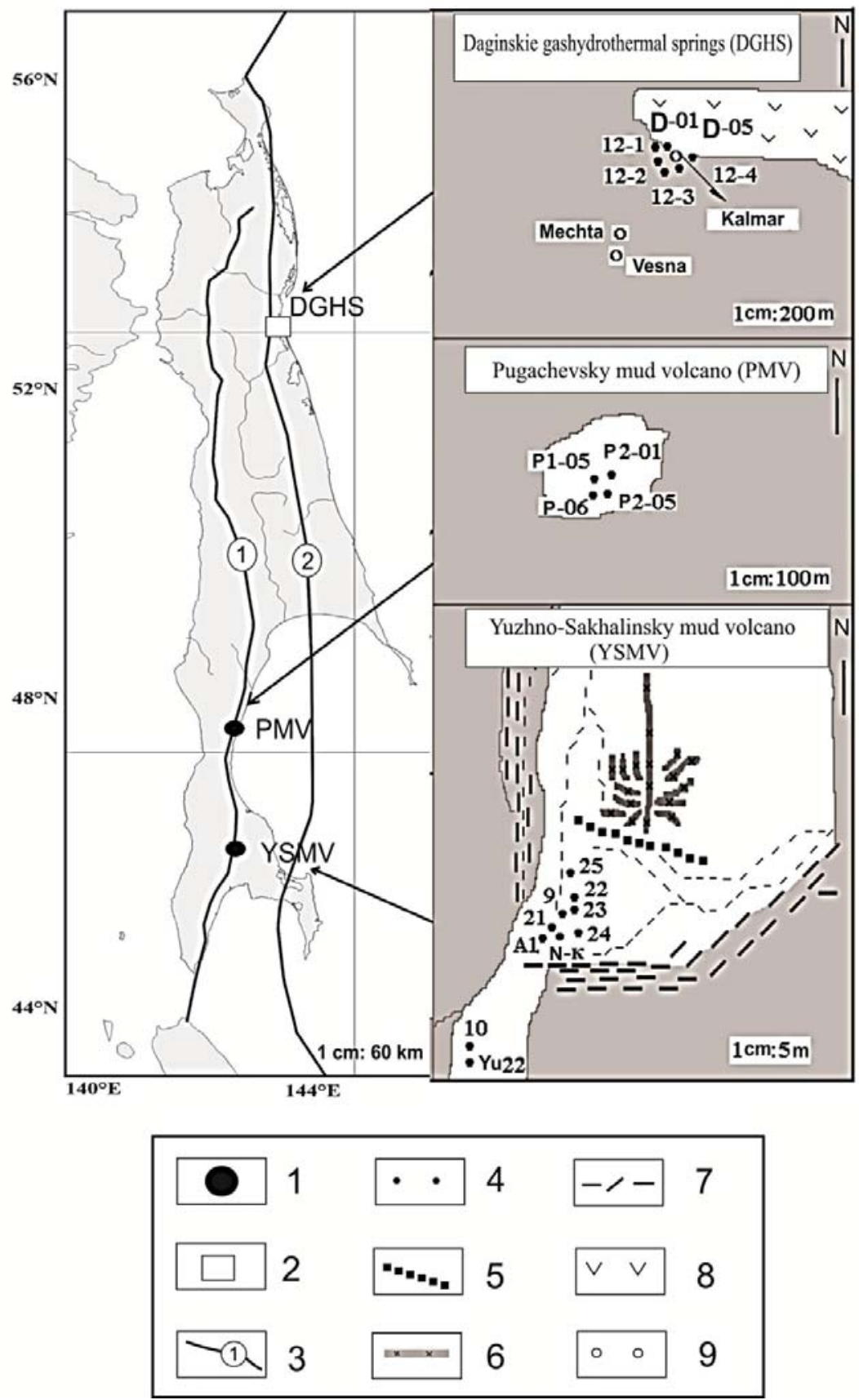

Figure 1. Scheme of mud volcanic sampling sites on Sakhalin Island: 1 - mud volcanoes; 2 - area of Daginsky geothermal system; 3 - faults (in brackets: 1 - Central Sakhalin fault, 2 - Hokkaido-Sakhalin fault); 4 - sampling sites and sample number; 5 - Zones of uplifting - subsidence of the mud field; 6-7 - fissures in mud field; 8 - area, flooded with sea tidal water; 9 - thermal springs. N-к -gryphon 'Naparnik'. Remark: The abbreviations are explained in the text 
Vietnam Journal of Earth Sciences, 40(1), 56-69
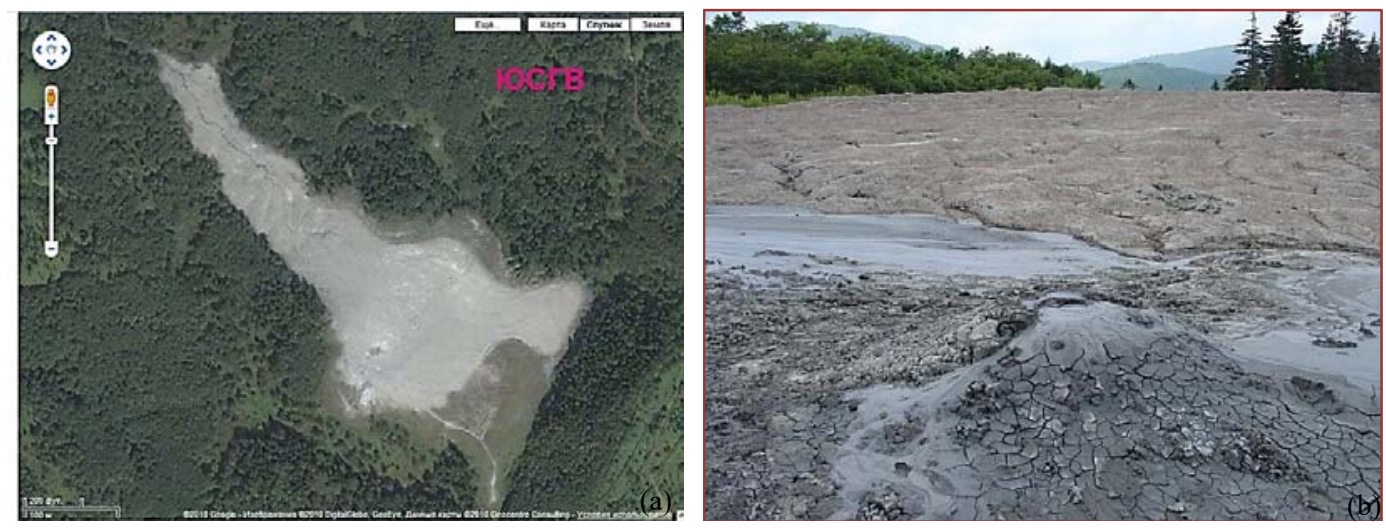

Figure 2. YSMV: a) general view of YSMV from satellite (google-earth); b) view to northern part of YSMV, gryphonYu-9
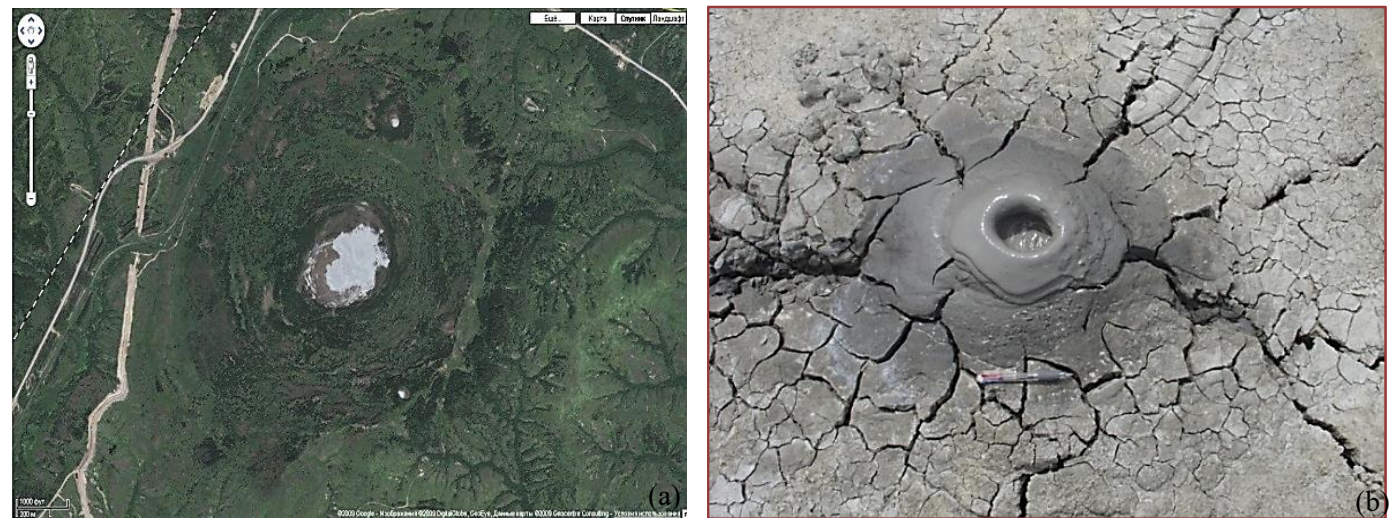

Figure 3. PMV: a) general view of PMV from satellite; b) passive gryphon at PMV, August 2005
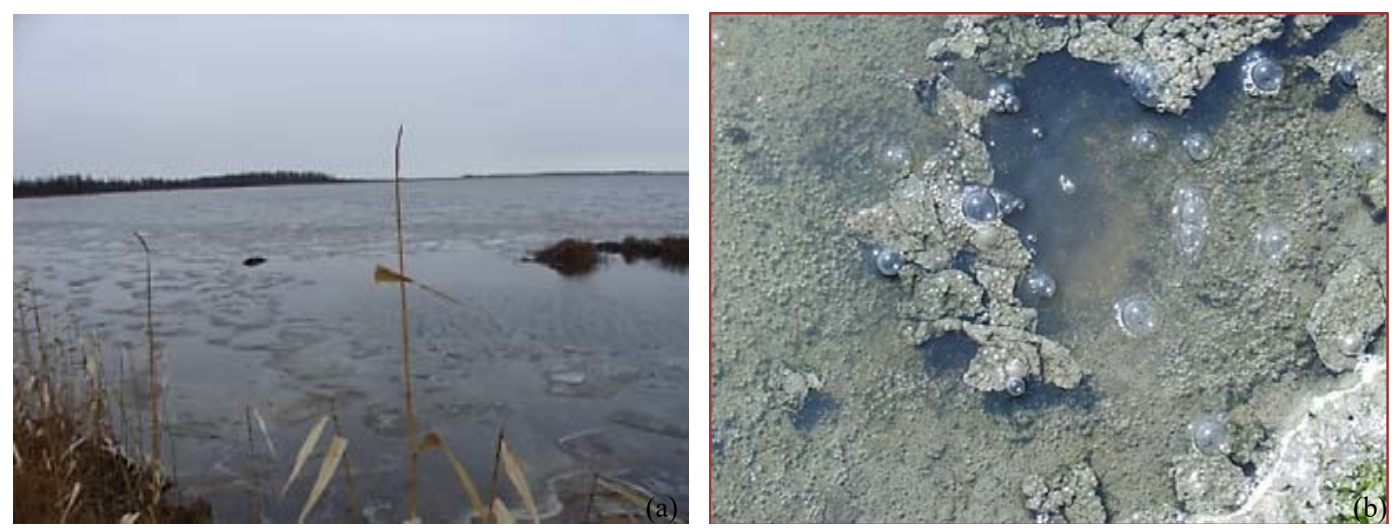

Figure 4. DGHS: a) view to Daginsky bay; b) output of gases from DGHS, in 2005

\section{Study methods}

Analysis of hydrocarbon gases, nitrogen and carbon dioxide was carried out in the gas geochemistry laboratory of POI FEB RAS using a two-channel gas chromatograph 'CrystalLux4000M' equipped with ionization and 
thermal conductivity sensors having a sensitivity of $10-5 \%$. For the analysis of helium and hydrogen, a portable gas chromatograph "Khromatek-Gasochrom 2000" was used with a sensitivity of 1-2 ppm for helium and hydrogen.

The elemental composition (gross content) in samples of recent mud volcano breccias was determined at an analytical chemistry laboratory in the Far Eastern Geological Institute, FEB RAS. The major (matrix) elements were measured using an inductively coupled plasma atomic emission spectrometry (ICPAES), whereas the trace elements were determined by inductively coupled plasma mass spectrometry (ICP-MS) method. The analytical error for the major elements is $\pm 1-2 \%$, for the trace elements is not higher than $\pm 15 \%$. The results of REE contents are interpreted in the form of chondrite normalization (Dubinin, 2006) and following the criteria for estimating the compositions of lanthanides, as follows:

$$
\mathrm{Eu}_{\mathrm{an}}=\mathrm{Eu} / \mathrm{Eu}^{*}=\mathrm{Eu}_{\mathrm{N}} /\left(\mathrm{Sm}_{\mathrm{N}}+\mathrm{Gd}_{\mathrm{N}} / 2\right. \text {; }
$$$$
\mathrm{Ce}_{\mathrm{an}}=\mathrm{Ce} / \mathrm{Ce}^{*}=\mathrm{Ce}_{\mathrm{N}} /\left(\mathrm{La}_{\mathrm{N}}+\mathrm{Pr}_{\mathrm{N}}\right) / 2
$$

$\mathrm{L}_{\mathrm{L}} / \mathrm{L}_{\mathrm{H}}=\left(\mathrm{La}_{\mathrm{N}}+2 \mathrm{Pr}_{\mathrm{N}}+\mathrm{Nd}_{\mathrm{N}}\right) /\left(\mathrm{Er}_{\mathrm{N}}+\mathrm{Tm}_{\mathrm{N}}+\mathrm{Yb}_{\mathrm{N}}+\mathrm{Lu}_{\mathrm{N}}\right)$

The mineral composition of the mud breccia was studied in thin sections and immersion method prepared according to a conventional procedure (Petelin, 1957). Silicate analysis of carbonates was performed also at the analytical chemistry laboratory of the Far Eastern Geological Institute, FEB RAS. The trace el- ement composition of carbonates is acquired using an IXA-8100 microscopic analyzer. The isotopic compositions of carbon and oxygen of authigenic carbonates, as well as carbon of methane and carbon dioxide, were determined at the laboratory of stable isotopes of the Far Eastern Geological Institute, FEB RAS, using a Finnigan MAT-252 mass spectrometer.

The sample processing for diatom analysis was carried out using heavy potassiumcadmium liquid chemical-technical technique (Diatomic algae of the USSR, 1974).

\section{Study results and discussions}

\subsection{Gasgeochemical features}

According to the gas specialization, YSMV and PMV belong to the carbonicmethane type of mud volcanoes. The predominant gas component for $\mathrm{YSMV}$ is $\mathrm{CO}_{2}$ (up to $74 \%$ ), while methane $\left(\mathrm{CH}_{4}\right)$ can reach as high as $24 \%$. The Pugachevsky group of mud volcanoes is characterized by a low emission intensity of free gases. In terms of quantitative ratio, the composition of PMV gases differs from the free gases of YSMV where the relative contents of $\mathrm{CO}_{2}$ and $\mathrm{CH}_{4}$, respectively, are $\sim 25 \%$ and $\sim 70 \%$ (with variations). Both mud volcanoes are characterized by the presence of heavy hydrocarbon gases to pentane inclusively, which indicate their common genesis (Table 1).

Table 1. Component compositions of free gases from YSMV, PMV, DGHS

\begin{tabular}{|c|c|c|c|c|c|c|c|c|c|c|c|c|}
\hline $\begin{array}{l}\frac{\tilde{d}}{0} \\
\stackrel{0}{0} \\
0\end{array}$ & $\mathrm{CO}_{2}, \%$ & $\mathrm{O}_{2}+\mathrm{Ar}, \%$ & $\mathrm{~N}_{2}, \%$ & $\mathrm{CH}_{4}, \%$ & $\mathrm{C}_{2} \mathrm{H}_{6}, \mathrm{ppm}$ & $\mathrm{C}_{3} \mathrm{H}_{8}, \mathrm{ppm}$ & $\mathrm{i}-\mathrm{C}_{4} \mathrm{H}_{10}, \mathrm{ppm}$ & $\mathrm{n}-\mathrm{C}_{4} \mathrm{H}_{10}, \mathrm{ppm}$ & $\mathrm{n}-\mathrm{C}_{5} \mathrm{H}_{12}, \mathrm{ppm}$ & He,ppm & $\mathrm{H}_{2}, \mathrm{ppm}$ & Year of sampling \\
\hline \multirow{6}{*}{ YSMV } & $69.2-83.9$ & $0.2-7.4$ & $2-5.2$ & $\overline{12.4-28.4}$ & $1.6-371$ & $7.5-426$ & $6.9-90.5$ & $0.6-108.7$ & nd & - & - & 2001 \\
\hline & $58.6-86.7$ & $0.1-0.9$ & $1.2-6.9$ & $11.8-33.3$ & $0.16-2855$ & $0.04-581$ & $0.005-128$ & $0.005-125$ & nd & - & - & 2005 \\
\hline & 68.3-78.8 & $0.1-3.2$ & $1.1-3.3$ & $12.7-35.6$ & $0.07-0.2$ & $0.02-0.05$ & $0.005-0.01$ & $0.006-0.01$ & $13.16-22.78$ & $11.8-40.9$ & $6.3-15$ & 2007 \\
\hline & $67.3-84.1$ & $0.2-1.2$ & $1.5-4.6$ & 13.3-29.8 & $0.1-0.25$ & $0.03-0.1$ & $0.005-0.1$ & $0.005-0.1$ & $15-22$ & - & - & 2009 \\
\hline & $68.4-92.5$ & $0.1-0.3$ & $1.24-2$ & $6.6-29.5$ & $0.06-0.27$ & $0.01-0.06$ & $0.003-0.01$ & $0.005-0.01$ & $7.5-15.2$ & $16.8-43.7$ & $0.2-1.6$ & 2011 \\
\hline & $72.2-87.0$ & $0.15-4.8$ & $1.4-17.5$ & $10.0-23.5$ & $0.12-0.24$ & $0.02-0.05$ & $0.0007-0.009$ & $0.0009-0.002$ & $3.1-7.6$ & $12-31.7$ & $0.4-5.7$ & 2013 \\
\hline \multirow{3}{*}{ PMV } & 8.6 & 18.4 & 60.4 & 12.6 & 92.8 & nd & nd & nd & & - & - & 2001 \\
\hline & $6.4-27$ & $2.7-21.8$ & - & $63.0-83.0$ & $0.5-5.6$ & $0.3-0.9$ & nd & nd & & - & - & 2005 \\
\hline & 18.8 & 5.3 & 12.6 & 63.3 & $0.02-0.03$ & nd & nd & nd & 0.32 & - & - & 2009 \\
\hline$\overline{\mathrm{DGHS}}$ & $0.3-1.0$ & $0.3-2.0$ & $6.0-9.0$ & 89.0- 93.2 & nd & nd & nd & - & & - & - & 2005 \\
\hline
\end{tabular}

Remark: Data were acquired at the Laboratory of Gasgeochemistryat POI FEB RAS, nd: not determined 
The Pugachevsky and YuzhnoSakhalinsky volcanoes are similar in many respects: they have similar mud field dimensions and the character of activity; they are situated in the field of gas-bearing, highly plastic Upper Cretaceous aleurolite-argillite formation and are confined to the Central Sakhalin fault of upthrust-overthrust type. Mud volcanoes are local gas drainage systems in the Earth's crust, but they are considered in the system of controlling linear structures. In this case, this is a deep-seated active fault with nearly north-south strike. This means that the fault zone is a single fluid-dynamic system, in some parts of which (especially, in the zone of fault crossing or near intrusion bodies), specific conditions appear for the formation of flows of gases with certain composition. In the southern part of the CentralSakhalin fault, the source of carbon dioxide for both YSMV and PMV, on the one hand, and in Sinegorskie mineral water springs, on the other hand, likely the same. Within these boundaries, the concentrations of $\mathrm{CH}_{4}$ and $\mathrm{CO}_{2}$ show characteristic variations: a considerable portion of methane in mud volcanoes (up to $60 \%$ ) is replaced sometimes by the predominance of carbon dioxide in Sinegorskie springs. This difference is determined by the different water filling in the mud volcanic channel: YSMV more saturated by water because its location is near freshwater spring. Carbon dioxide dissolves in the water in large portions. In opposite, the PMV has low content of water in the mud flow. Therefore, methane dominates in this PMV as compared to the YSMV. Taken into account the equal water saturation of the both mud volcanoes, we could expect similar proportion between the methane and carbon dioxide. But this study needs additional methods. Remarkably, basic rock diapirs (diabas) located close to the YSMV could also be source of the carbon dioxide.

It should be noted that, in terms of component composition, the PMV gases match with the gases of the Northern Sakhalin oil fields (Siryk, 1968). The peculiarities of the geological development of formation area of the mud volcanoes definitely indicate a greater probability of finding hydrocarbon deposits in the sedimentary thickness at the Pugachevsky volcano region (Veselov et al., 2012). For YSMV, the isotopic composition of carbon of carbon dioxide $\delta^{13} \mathrm{C}$ is from -2.8 to $-2.7 \%$ $\mathrm{PDB}$ and $\delta^{13} \mathrm{C}$ of methane is $-27 \mathrm{PDB}$; for the Pugachevsky mud volcanic group, $\delta^{13} \mathrm{C}$ of methane is $-24.9 \div-20.9 \%$ PDB, for carbon dioxide $\delta^{13} \mathrm{C}$ is $-4.1 \%$ PDB.

The main component of the spontaneous DGHS gas is methane (up to $93 \%$ by volume) with $\delta^{13} \mathrm{C}-\mathrm{CH}_{4}-54 \div-57 \%$ PDB. The methane concentration from DGHS is genetically close to the methane in oil and gas-bearing fields of Sakhalin Islandand the nearest shelf, where concentrations are up to $10,000 \mathrm{nl} / 1$ (Shakirov et al., 2012).

As a result of long-term observations (from 2001 to 2013), the average chemical composition of free gases of Sakhalin mud volcanoes was established during passive periods and shown in Table 1.

The idea of a deep gas source in the Pugachevsky and Yuzhno-Sakhalinsky mud volcanoes is in good agreement with the opinion of a number of researchers (Veselov et al., 2012; Ershov et al., 2011) that mud volcanoes are generated in sedimentary strata at depths about 7-8 km (calculated using isotope geothermometers), where thermobaric conditions are favorable for the formation of large volumes of gases.

There is an empirical dependence of methane carbon isotope composition on temperature and its generation (Prasolov, 1990). According to this dependence the average value of $\delta^{13} \mathrm{C}$ methane of the Yuzhno-Sakhalinsky mud volcano corresponds to temperature of methane genesis of about $320-340^{\circ} \mathrm{C}$. The average geothermal gradient in the southern part of Sakhalin Island calculated according to work of Veselov and Soinov (1997), shows about $41.1^{\circ} \mathrm{C} / \mathrm{km}$. Therefore, we believe that a methane source depth for the volcano is located between 7.8 and $8.3 \mathrm{~km}$.

Extent of isotope division of carbon in the $\mathrm{CO}_{2}-\mathrm{CH}_{4}$ system depends on temperature conditions of gas generation. The range of 
temperature of isotope balance in this system calculated for average values $\delta^{13} \mathrm{C}-\mathrm{CH}_{4}$ and $\delta^{13} \mathrm{C}-\mathrm{CO}_{2}$ by formulas from work of Horita (2001), is $330-350^{\circ} \mathrm{C}$, corresponding to the range of generation depths between 8.0 and $8.5 \mathrm{~km}$.

\subsection{Geochemical features of the mud breccias}

Collected samples of recent mud volcano breccias from YSMV and PMV were dark gray liquid silt-pelitic sediment containing a small amount of sand. The mineralogical study of the samples identified two classes of minerals belonging to carbonates or sulphides. Carbonates are represented by well-formed crystals of beige-brown and red-brown color which constitute $92-97 \%$ of the heavy fraction. The chemical and microprobe analytical results shown in, respectively, Table 2 and Table 3 , suggest their compositions corresponding to the magnesian-ferric variations of sideritesideroplezites (Sorochinskaya et al., 2008).

Table 2. Chemical and isotopic compositions of YSMV major natural gases

\begin{tabular}{|c|c|c|c|c|c|c|}
\hline $\mathrm{CH}_{4}, \%$ & $\delta^{13} \mathrm{C}_{\mathrm{pdb}}-\mathrm{CH}_{4}, \%$ & $\mathrm{CO}_{2}, \%$ & ${ }^{13} \mathrm{C}_{\mathrm{pdb}}-\mathrm{CO}_{2}, \%$ & $\mathrm{He}, \mathrm{ppm}$ & $\mathrm{H}_{2}, \mathrm{ppm}$ & $\begin{array}{c}\text { Year of sam- } \\
\text { pling }\end{array}$ \\
\hline $13.6-29.9$ & $-29.8-27.3$ & $67.5-84.1$ & $-6.3-4$ & \multirow[b]{2}{*}{-} & \multirow[b]{2}{*}{ - } & \multirow[b]{2}{*}{2009} \\
\hline$\overline{23.9(49)}$ & $\overline{-28.8(49)}$ & $73(49)$ & $\overline{-5.3(49)}$ & & & \\
\hline $17.9-23.9$ & $-29.3-28.9$ & $74-80.4$ & $-5.4-4.7$ & \multirow[b]{2}{*}{-} & \multirow{2}{*}{-} & \multirow{2}{*}{2010} \\
\hline $21.5(5)$ & $-29.06(5)$ & $76.5(5)$ & $-5.1(5)$ & & & \\
\hline $6.6-29.5$ & $-27.6-30.3$ & $65.8-80.3$ & $-4.7-6.7$ & $16.8-32.4$ & $0.2-1.6$ & \multirow{2}{*}{2011} \\
\hline $23.1(15)$ & $28.7(15)$ & $74.9(15)$ & $\overline{-5.6(15)}$ & $28.3(15)$ & $\overline{0.7(15)}$ & \\
\hline $10.9-24.2$ & \multirow[b]{2}{*}{ - } & $72.2-87$ & \multirow[b]{2}{*}{ - } & $12-30.2$ & $0.4-24.6$ & \multirow[b]{2}{*}{2013} \\
\hline$\overline{18.9(24)}$ & & $\overline{77.9(24)}$ & & $\overline{23.8(24)}$ & $2.9(24)$ & \\
\hline
\end{tabular}

Remark: In numerator - minimum/maximum values, in denominator - an average, in () - the number of the analysed samples

Table 3. Chemical composition of major components in authigenic carbonates from YSMV and PMV (in mass\%)

\begin{tabular}{|c|c|c|c|c|c|c|c|c|c|c|c|c|c|}
\hline \multirow{2}{*}{ Object } & \multicolumn{13}{|c|}{ Components } \\
\hline & $\mathrm{SiO}_{2}$ & $\mathrm{Al}_{2} \mathrm{O}_{3}$ & $\mathrm{TiO}_{2}$ & $\mathrm{FeO}$ & $\mathrm{Fe}_{2} \mathrm{O}_{3}$ & $\mathrm{MnO}$ & $\mathrm{CaO}$ & $\mathrm{MgO}$ & $\mathrm{K}_{2} \mathrm{O}$ & $\mathrm{Na}_{2} \mathrm{O}$ & $\mathrm{P}_{2} \mathrm{O}_{5}$ & $\mathrm{H}_{2} \mathrm{O}$ & * \\
\hline YSMV & 8.4 & 2.65 & 0.056 & 32.45 & 5.73 & 0.52 & 6.60 & 5.34 & 0.34 & 0.47 & 0.07 & 0.64 & 36.4 \\
\hline PMV & 8.8 & 2.65 & 0.056 & 32.21 & 5.86 & 0.14 & 6.53 & 5.80 & 0.37 & 0.39 & 0.09 & 0.37 & 36.3 \\
\hline
\end{tabular}

(*): loss on ignition

The maximal contents of $\mathrm{Mn}(4.68 \%), \mathrm{Hg}$ $(0.59 \%)$ and $\mathrm{Sr}(0.25 \%)$ are in carbonates collected in YSMV from an active gryphon (sample Yu-9 / 17.08). The isotope composition of carbon $\left(\delta^{13} \mathrm{C}\right)$ of authigenic carbonates from YSMV and PMV varies within narrow limits, from -0.3 to $-0.7 \%$ PDB, $\delta^{18} \mathrm{O}$ values varying from 2.6 to $4.4 \%$ PDB (Table 4 ).

Samples from DGHS are represented by pelite - aleurite sediment of dark gray color with up to $70 \%$ organic remains (spicules of sponges, diatoms). The main authigenic mineral is framboidal pyrite (up to $90 \%$ of the heavy fraction) in the form of nonmagnetic pseudomorphs by organic residues and dark gray globules. The main lines on the X-ray diffraction pattern of sample D-1: 2.729 (10); 2.428 (7); 2.226 (5); 2.044 (2); 1.636 (6). Single crystals of red-brown sideroplezites are noted, which are similar in composition to those previously described in the samples from YSMV and PMV (Table 4). 
Vietnam Journal of Earth Sciences, 40(1), 56-69

Table 4. Compositions of trace elements in individual crystals in authigenic carbonates determined by microscopic analysis

\begin{tabular}{|c|c|c|c|c|c|c|c|c|}
\hline \multirow{2}{*}{ Object } & \multirow{2}{*}{ Sample } & \multicolumn{7}{|c|}{ Elemental content, wt.\% } \\
\hline & & $\mathrm{Mn}$ & $\mathrm{Ni}$ & $\mathrm{Cu}$ & $\mathrm{Zn}$ & $\mathrm{Sr}$ & $\mathrm{Ba}$ & $\mathrm{Hg}$ \\
\hline \multirow{9}{*}{ YSMV } & Yu-22(1) & 0.77 & nd & nd & 0.19 & 0.16 & 0.14 & 0.49 \\
\hline & $\mathrm{Yu}-22(2)$ & 0.82 & nd & 0.13 & 0.1 & nd & nd & nd \\
\hline & $\mathrm{Yu}-22(3)$ & 0.43 & 0.09 & 0.09 & 0.03 & 0.17 & nd & 0.14 \\
\hline & $\mathrm{Yu}-22(4)$ & 0.93 & 0.16 & 0.16 & 0.1 & 0.08 & 0.08 & nd \\
\hline & $\mathrm{Yu}-22(5)$ & 1.92 & nd & 0.09 & 0.06 & 0.11 & 0.11 & nd \\
\hline & Yu-9/17.08(6) & 0.59 & 0.15 & 0.13 & 0.11 & 0.21 & nd & 0.38 \\
\hline & Yu-9/17.08(8) & 0.41 & 0.13 & 0.19 & nd & 0.23 & nd & nd \\
\hline & Yu-9/17.08(11) & 4.68 & 0.1 & 0.02 & nd & nd & nd & 0.59 \\
\hline & Yu-9/17.08(12) & 1.55 & nd & nd & nd & 0.25 & 0.1 & nd \\
\hline \multirow{3}{*}{ PMV } & P-06(13) & 0.31 & 0.14 & 0.17 & 0.12 & 0.16 & 0.13 & nd \\
\hline & P-06(14) & 0.15 & nd & nd & nd & 0.17 & nd & 0.44 \\
\hline & P-06(15) & 0.18 & nd & nd & nd & 0.29 & 0.07 & 0.45 \\
\hline \multirow{6}{*}{ DGHS } & D1/1(16) & 0.81 & 0.11 & nd & 0.03 & 0.13 & 0.05 & nd. \\
\hline & D1/1(19) & 0.72 & nd & 0.04 & 0.07 & nd & 0.11 & nd \\
\hline & $\mathrm{D} 1 / 1(21)$ & 0.55 & nd & 0.11 & 0.09 & 0.13 & nd & 0.08 \\
\hline & $\mathrm{D} 1 / 1(22)$ & 0.54 & nd & 0.03 & nd & 0.24 & 0.2 & nd \\
\hline & $\mathrm{D} 1 / 1(23)$ & 0.61 & 0.13 & 0.04 & nd & 0.12 & nd & nd \\
\hline & $\mathrm{D} 1 / 1(23)$ & 0.63 & nd & 0.02 & 0.05 & 0.19 & 0.15 & nd \\
\hline
\end{tabular}

Remarks: Yu-22(1) - Yu-22(5) - individual crystals of sideroplezites selected from the sample

Yu-22; Yu-9/17.08(6) - Yu-9/17.08(12) - individual crystals of sideroplezites selected from the sample Yu-9/17.08; P-06(13) - P-06(14) - crystals of sideroplezites selected from the sample P-06; D1/1(16) - D1/1(16) - crystals of sideroplezites selected from the sample D1/1; nd- not determined

Analysis of diatom flora in samples from DGHS showed the prevalence of marine and brackish-water species, among which the marine plankton-benthic species Paralia sulcata (Ehrenberg) Cleve, characteristic of shelf waters, dominates (Diatoms eic algae of the USSR, 1974; Hasle and Syvertsen, 1996). A significant number of freshwater diatoms (up to $32 \%$ ) and an admixture (up to $5.5 \%$ ) of marine species, extinct in the Neogene, (Actinocyclus ingens Rattray, Ikebea tenuis (Brun) Akiba, Cosmiodiscus insignis (Brun) Jousé, Eupyxidicula zabelinae (Jousé) Blanco \& Wetzel Pyxidicula zabelinae (Jousé) Makarova et Moisseeva et al.), supposedly introduced from the clay strata of the Okobykai and Nutovsky Neogene formations distributing lower at a relatively shallow depth (Gladenkov (Editor), 1998; Lobodenko, 2010; Zharov et al., 2013). This indicates the existence of an active fluid dynamic system, which drains oil and gas bearing complexes (Table
5). Elemental compositions of mud volcanic breccias from YSMV, PMV, and DGHS.

The chemical compositions of the mud volcanic breccias (Table 5) were normalized to their average contents (Clarke: $\mathrm{C}$ ) in clays and shales (Vinogradov, 1962; Grigoriev, 2008). Most of the elemental contents in the YSMV breccia are in the range of $0.8-1.2 \mathrm{xC}$, which is comparable to the Clark content (C) of each element. Elevated concentrations in the mud volcanic breccia presented by the $\mathrm{Na}$ (2.9-5.2 $\times$ C), Li (1.5-2.0), Zn (1.4-1.9) and Sn (1.6-2.4), although the contents of $\mathrm{Mn}, \mathrm{Ca}, \mathrm{Zr}$, $\mathrm{Mo}, \mathrm{Cd}, \mathrm{Hf}, \mathrm{U}$ are lower than their Clarke values $(<0.5 \times \mathrm{C})$.

A similar feature is observed in the mud volcanic breccia from PMV that, the content of most elements is close to their Clarke concentrations. The samples contain rather high $\mathrm{Na}(2.9 \times \mathrm{C}), \mathrm{Li}(1.7 \times \mathrm{C}), \mathrm{Zn}(1.6 \times \mathrm{C}), \mathrm{Sn}$ (1.9-4.3 $\times \mathrm{C})$; whereas $\mathrm{Mn}, \mathrm{Ca}, \mathrm{Zr}, \mathrm{Mo}, \mathrm{Cd}$, $\mathrm{Hf}, \mathrm{Ta}$ and $\mathrm{U}$ concentrations are lower than their Clarke values $(<0.5 \times \mathrm{C})$. 
Shakirov R.B., et al./Vietnam Journal of Earth Sciences 40 (2018)

Table 5. Elemental compositions of mud volcanic breccia from YSMV, PMV, DGHS

\begin{tabular}{|c|c|c|c|c|c|c|c|c|c|c|c|c|c|c|c|c|c|c|c|c|c|c|}
\hline \multirow{2}{*}{$\begin{array}{l}\overrightarrow{\tilde{c}} \\
\stackrel{\Phi}{\tilde{E}} \\
\underline{\Psi}\end{array}$} & \multicolumn{12}{|c|}{ YSMV } & \multicolumn{4}{|c|}{ PMV } & \multicolumn{6}{|c|}{ DGHS } \\
\hline & 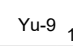 & $\begin{array}{r}Y \\
17\end{array}$ & & $\begin{array}{r}\text { Yu-10 } \\
17 \quad 08\end{array}$ & $\begin{array}{r}\text { Yu- } \\
22 \_01\end{array}$ & $\mathrm{~N}-\mathrm{k}$ & A-1 & 1 & 2 & E-23 & 24 & $E-25 \mathrm{~F}$ & P2/2-01 & $1 \mathrm{~F}$ & 5 & $5 P-0$ & 1 & & & & & D-12- \\
\hline \multicolumn{23}{|c|}{ Weight.\% } \\
\hline $\mathrm{Ti}$ & 0.37 & 0.36 & 0.36 & 0.36 & 0.37 & 0.36 & 0.35 & 0.36 & 0.35 & 0.35 & 0.3 & 0.36 & .36 & 0.36 & 0.36 & 37 & .22 & 26 & 27 & 27 & 0.20 & \\
\hline Al & 72 & 3.64 & 62 & 7.92 & 8.72 & 45 & 27 & 8.51 & 41 & 3.62 & 8.59 & & 58 & 30 & .15 & קר & 05 & & & 13 & 14 & 6.4 \\
\hline $\mathrm{Fe}$ & 58 & 3.09 & 3.84 & 2.77 & 3.78 & 56 & 3.78 & 3.92 & 95 & .44 & .80 & 85 & 72 & 75 & 4.60 & 60 & 08 & 11 & 00 & 19 & 75 & 1.8 \\
\hline $\mathrm{Ca}$ & 51 & 0.39 & .54 & 0.50 & 0.82 & .54 & 1.63 & .58 & .68 & .55 & 0.63 & 0.70 & 46 & 88 & 0.63 & .50 & 52 & 5 & .4 & 66 & 51 & 0.6 \\
\hline $\mathrm{Mg}$ & 01 & .95 & .03 & 1.20 & 1.03 & .01 & 1.06 & 1.04 & 1.05 & 0.99 & 1.05 & 1.04 & 91 & 9 & 0.95 & .88 & 38 & 17 & 45 & .47 & 43 & 0.57 \\
\hline K & 49 & 2.49 & .42 & 2.41 & 2.47 & 2.44 & 2.37 & 2.43 & 2.40 & 2.48 & 2.44 & 4 & 43 & 38 & 2.33 & 40 & 51 & .32 & 33 & .29 & 42 & 2.32 \\
\hline $\mathrm{Na}$ & 93 & 1.97 & .89 & 3.40 & 2.05 & 1.96 & 2.15 & 2.01 & 2.00 & 2.24 & 18 & 14 & 34 & & 1.90 & 87 & 03 & .03 & 15 & 08 & 67 & 1.94 \\
\hline $\mathrm{Mn}$ & 0.04 & 0.03 & 0.05 & 0.02 & 0.06 & 0.04 & 0.05 & 0.05 & 0.05 & 0.04 & 0.04 & .05 & 02 & & 0.03 & 02 & 02 & 02 & 02 & 02 & 02 & .01 \\
\hline $\mathrm{P}$ & 66 & 0.06 & 0.06 & 0.06 & 0.06 & 0.06 & 0. & 0.06 & 0.06 & 0.06 & 0.06 & .00 & 06 & 0 & 0.06 & 00 & 01. & .02 & 01 & 01 & 0.02 & 0.0 \\
\hline \multicolumn{23}{|c|}{$\mathrm{g} / \mathrm{t}$} \\
\hline $\mathrm{Li}$ & 52.54 & 91 & 50.28 & 13 & 25 & 53.94 & 51.96 & 69 & 3 & 54.70 & 53.15 & 3 & 24 & 5 & 35 & 73 & 98 & 03 & 80 & .90 & .40 & 3.70 \\
\hline $\mathrm{Be}$ & 1.72 & 1.70 & 1.59 & 1.48 & 52 & 1.68 & 1.71 & 1.61 & 88 & 1.69 & 6 & 2 & 7 & 75 & 1.84 & 80 & 11 & 7 & & 19 & 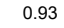 & 1.30 \\
\hline $\mathrm{Sc}$ & 16.50 & .00 & 17.20 & 12.70 & 17.30 & 16.20 & 16.90 & 17.40 & 18.90 & 16.40 & 17.20 & 7.00 & 15.40 & 15.30 & 17.50 & 15.00 & .70 & 8.20 & 65 & 27 & 32 & .0 \\
\hline V & 98.60 & .00 & .10 & 93.70 & 99.80 & 96.80 & 95.201 & 101.601 & 102.90 & 97.70 & 98.50 & 7.50 & 86.30 & 83.90 & 86.10 & 83.10 & 30.10 & 60 & 7.90 & 7.10 & 30 & 86.00 \\
\hline $\mathrm{Cr}$ & 33 & .78 & 34 & 43.18 & 5.28 & 5.97 & 44.83 & 45.53 & 46.00 & 46.08 & 45.60 & 64.26 & 2 & 46.04 & 46.23 & 10 & 3 & 0 & 3 & 0 & 0 & 46.60 \\
\hline Co & 40 & 10 & 30 & 16.00 & 7.50 & 7.20 & 16.50 & 16.60 & .40 & 17.50 & 16.90 & 6.80 & 0 & 16 & 16.00 & 1 & 7.30 & 9.00 & 0 & 4.98 & .60 & 5 \\
\hline $\mathrm{Ni}$ & .90 & 80 & 28.30 & 27.30 & .20 & 29.70 & 31.50 & 29.20 & 1.40 & 28.80 & 30.50 & 33.90 & 26.60 & 27.70 & 28.50 & 0 & 17.80 & 20.90 & 1 & 18.30 & 1 & 2 \\
\hline $\mathrm{Cu}$ & .50 & .50 & 36.50 & 36.60 & .70 & 37.70 & 38.80 & 6.60 & 37.30 & 38.10 & 35.80 & 35.50 & 30 & 27.30 & 27.70 & 2 & 30 & 6.30 & 90 & 52 & 40 & $y$ \\
\hline $\mathrm{Zn}$ & 70 & 10 & 85.80 & 70.70 & 30 & 83.00 & 98.90 & 83.40 & 83.00 & 80.20 & 82.70 & 87.10 & 85.80 & 83.30 & 83.20 & 50 & 35.40 & 3 & . & 0 & 0 & 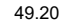 \\
\hline $\mathrm{Ga}$ & 16.99 & 17.38 & 16.25 & 15.77 & 16.64 & 16.97 & 16.27 & 16.43 & 16.07 & 16.92 & 16.36 & 16.52 & 16.09 & 16.22 & 15.75 & 79 & 10.63 & 11.77 & 30 & 50 & 10 & 1 \\
\hline As & 72 & 7.34 & 8.06 & 6.06 & 8.16 & 8.72 & 8.07 & 8.03 & 62 & 8.54 & 8.50 & 01 & 10.16 & 10.95 & 10.73 & 50 & .32 & 20 & & 35 & & \\
\hline $\mathrm{Rb}$ & 104.641 & 102.561 & 100.39 & 79.221 & 100.6 & 103.72 & 98.98 & 98.58 & 98.391 & 104.97 & 98.58 & 99.921 & & 105.4 & 100.8 & 106.6 & 51 & 84.62 & & .0 & .0 & \\
\hline $\mathrm{Sr}$ & 219.701 & 193.1 & 220.402 & & & 230.602 & & 222.402 & 220. & & & & 7 & 220.9 & 253.7 & & & 219.8 & & & & \\
\hline Y & 19.00 & 18.10 & 18.90 & 10.70 & 20.20 & 19.20 & 19.10 & 20.00 & 20.30 & 0 & 19 & & & 18 & 9 & & & 2 & & & 35 & \\
\hline $\mathrm{Zr}$ & 9 & 6 & 6 & 86.70 & 9 & 123 & 88 & 90.52 & 9 & 90 & 91.02 & 3 & 78.07 & 71.07 & 77.65 & & 42.79 & 52.03 & & 0 & 0 & 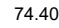 \\
\hline $\mathrm{Nb}$ & & 19 & 7. & 7.50 & 7.67 & 7.95 & 7.67 & 57 & & & 7.63 & & & & 8.47 & & & & & & & \\
\hline Mo & 0. & 39 & 0.42 & 0. & 0. & 0 & 0. & 0.70 & .51 & 0. & 0.3 & 0.50 & . & 0.49 & 0.6 & & 71 & 1.03 & & 47 & & .7 \\
\hline $\mathrm{Ag}$ & 0 & 0.15 & 0. & 0.16 & 0.15 & 0.21 & 0. & 0. & 16 & & 0. & 0.15 & 0.16 & & 0.1 & & 16 & 0.1 & & 19 & & .1 \\
\hline $\mathrm{Cd}$ & 13 & 17 & 0.09 & 0.11 & 0. & 0.13 & 0.1 & 0.1 & 13 & 0.13 & 0.1 & 0.13 & 0.16 & 0.10 & 0.09 & 0.09 & 0.26 & 0.2 & 1.22 & 29 & & .25 \\
\hline Sn & 45 & 6.42 & 8.41 & 6.39 & 5.67 & 7.01 & 6.69 & 6.88 & 7.23 & 6.5 & 7.51 & 6.31 & 15.0 & 7.7 & 6.69 & 6.6 & 01 & 0 & 1.70 & 61 & 1.28 & $1.8 \mathrm{~s}$ \\
\hline Cs & & 7.3 & 1. & 7.48 & 7.77 & 8.05 & 7. & 7.57 & 51 & & 1. & 31 & 29 & 7 & 7.21 & & 19 & & 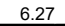 & 8 & & 84 \\
\hline $\mathrm{Ba}$ & & & & & & & & & & & & & & & & & & & & & & \\
\hline La & & & & & & & & & & & & & & & & & & 57 & 80 & 40 & 70 & \\
\hline $\mathrm{Ce}$ & 4 & +47 & & 96 & & & & & & 0 & & & & 46 & 4 & & & 37 & 30 & & 2.0 & \\
\hline $\operatorname{Pr}$ & & & & & 3 & & 06 & & & 6 & 34 & & & & & 7 & & & & & 75 & \\
\hline $\mathrm{Nd}$ & & 19.85 & & & & & & $4 \quad 19.98$ & & & 18 & & & & 2 & & & 1 & 0 & & 60 & \\
\hline $\mathrm{s}$ & & & & & & & & & & & & & & & & & & & & & & \\
\hline $\mathrm{Eu}$ & & 0.73 & & 0 & 0 & & & & & & 0.79 & & & & & & & & & & & \\
\hline $\mathrm{Gd}$ & & 3 & & & 3 & & & 3.5 & & & & & & & & & & & & & & \\
\hline $\mathrm{Tb}$ & & 50 & 4 & & 0 & & & 0.5 & & & 0.5 & & & & & & & & & & & \\
\hline Dy & & & 3 & & & & & 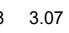 & & & 3 & & & & 07 & & & & & & & \\
\hline Ho & & 55 & 57 & & 8 & 0. & & 1 & & & 0 & & & & 60 & & 35 & & & 57 & & \\
\hline $\mathrm{Er}$ & 6 & 1.79 & $\begin{array}{ll}9 & 1.90\end{array}$ & 18 & $\begin{array}{ll}8 & 1.91\end{array}$ & 2.03 & 3 & 1.76 & 6 & & 1.82 & 1.75 & 1. & 1.66 & 0 & 1. & 06 & & .56 & 60 & 1.28 & 77 \\
\hline $\mathrm{Tm}$ & & 26 & 0.26 & 16 & 6 & . & & D & & & 0 & 24 & & 0 & 23 & & 14 & & 23 & 23 & & \\
\hline $\mathrm{Yb}$ & & $5 \quad 2.53$ & 61 & 95 & 2.68 & 2.54 & & 66 & & & 2. & & & & 65 & & 29 & 4 & .51 & 53 & .23 & \\
\hline Lu & & 0.27 & 25 & 17 & 0.25 & 25 & p & 0.27 & $\gamma$ & 0.26 & 0 & 4 & & 0.21 & 22 & 0.24 & 15 & 5 & .23 & 22 & .18 & \\
\hline $\mathrm{Hf}$ & & 2.71 & 81 & 48 & 2.79 & 2 & 2.63 & + & 4 & 2.63 & 2.57 & 2.63 & & 2.29 & 36 & 2.44 & 40 & 1.50 & 1.81 & 06 & 1.47 & 09 \\
\hline $\mathrm{Ta}$ & 3 & 0.52 & 0.51 & $1 \quad 0.50$ & 51 & 0.52 & ? & .52 & 50 & 0.52 & 0.51 & 48 & 0.59 & 58 & 59 & 0. & 32 & 41 & .65 & 68 & 50 & 85 \\
\hline W & 2 & 1.98 & 2.2 & 96 & 26 & 55 & 72 & .27 & 19 & 53 & 2.28 & 36 & 3.23 & 60 & .50 & 3.57 & 97 & 25 & 38 & 45 & 98 & 69 \\
\hline $\mathrm{Pb}$ & 16.06 & 16.46 & $\begin{array}{ll}6 & 15.84\end{array}$ & .77 & $\begin{array}{ll}7 & 16.63\end{array}$ & 17.01 & 17.05 & 15.86 & $6 \quad 15.91$ & 16.19 & 18.49 & 16.57 & 15.75 & 17.14 & 17.00 & 16.56 & 10.24 & 44 & 20.70 & 19.60 & 18.40 & 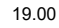 \\
\hline Th & 9.62 & 2 9.83 & 9.47 & $\begin{array}{ll}7 & 7.31\end{array}$ & 119.62 & 9.51 & 9.37 & .46 & 9.15 & 9.41 & 9.26 & 9.22 & 9.79 & 9.64 & 9.60 & 9.99 & 10 & 05 & 7.99 & 9.29 & 6.27 & 11.00 \\
\hline U & 1.86 & 2.04 & 1.78 & $\begin{array}{ll}8 & 1.55\end{array}$ & 1.88 & 1.78 & 1.81 & 1.81 & 1.79 & 1.86 & 1.79 & 1.85 & 1.92 & 1.82 & 1.87 & 1.91 & 24 & .44 & 1.98 & .08 & 1.60 & 2.49 \\
\hline$\Sigma$ REE & 111.2 & 2 110.4 & $4 \quad 109.7$ & 59.8 & $\begin{array}{ll}8 & 112.5\end{array}$ & f 109.3 & 3106.4 & 110.0 & 107.5 & 107.1 & 104.9 & 105.1 & 107.7 & 109.4 & 107.8 & 111.1 & 9.7 & 89.0 & 112.4 & 127.8 & 97.5 & 138.7 \\
\hline$L a_{N} / Y b_{N}$ & 5.53 & 5.56 & 6 & 33 & 3 & 5 & $t$ & 6 & & 1 & 4.87 & 2 & 5. & 64 & 4.82 & 5.80 & 38 & .46 & 10.18 & 11.63 & 10.80 & 11.48 \\
\hline $\mathrm{Gd}_{N} / Y \mathrm{~b}_{N}$ & N 1.22 & ? 1.16 & 1.17 & $\begin{array}{ll}7 & 0.74\end{array}$ & 1.01 & 1.18 & $\begin{array}{ll}3 & 1.20\end{array}$ & 1.19 & 1.13 & 1.20 & 1.11 & 1.11 & 1.31 & 1.40 & 1.19 & 1.42 & 59 & 1.71 & 1.97 & 2.16 & 2.09 & 13 \\
\hline $\mathrm{Eu} / \mathrm{Eu}^{*}$ & 0.62 & ? 0.59 & 0.64 & $4 \quad 0.62$ & 0.63 & 0.66 & 0.65 & 0.64 & 0.62 & 0.64 & 0.65 & 0.64 & 0.64 & 0.62 & 0.62 & 0.62 & .73 & .71 & 0.73 & 0.65 & 0.67 & .63 \\
\hline $\mathrm{Ce} / \mathrm{Ce}^{*}$ & 1.07 & 1.08 & 1.08 & $\begin{array}{ll}8 & 1.08\end{array}$ & 1.08 & 1.10 & 1. & 1.09 & 1.10 & 8 & 1.10 & 1.08 & 1 & 1.08 & 1.11 & 1.08 & 01 & 1 & 00 & .01 & 02 & .00 \\
\hline$/ L n_{H}$ & 4.45 & 4.43 & 4.24 & $\begin{array}{l}4 \quad 3.29 \\
4\end{array}$ & $\begin{array}{ll}9 & 4.27\end{array}$ & 4.15 & 4.29 & 4.27 & 4.06 & 4.28 & 4.04 & 4.25 & 4.47 & 4.84 & 4.33 & 4.84 & 6.15 & 6.31 & 6.44 & 7.24 & 6.84 & .17 \\
\hline
\end{tabular}

Elemental concentrations in ooze samples collected from the Daginsky gasgeothermal field are much lower than in the samples from YSMV and PMV. The ratios between the bulk major to minor elemental concentrations are about $\mathrm{C}_{\text {sample }} /$ Clarke $<0.6$; while the concentration ratios in DGHS oozesamples are higherthan their Clarke contents, e.g., $\mathrm{Cd}=2.2-3.4$ 
$\times \mathrm{C})$ and $\mathrm{Pb}=0.7-1.5 \times \mathrm{C}$. The concentrations of other elements such as $\mathrm{Cr}, \mathrm{Zn}, \mathrm{Sr}, \mathrm{Ag}$ and $\mathrm{Ba}$ are comparable with their Clark concentrations of about $0.7-1.3 \times \mathrm{C}$. The increase in the content of $\mathrm{Cd}$ and $\mathrm{Pb}$ in the sediment is obviously associated with the processes occurring at the river-sea geochemical barrier, where the precipitation of suspended and dissolved forms of metals increases sharply (Oreshkin and Gordeev, 1983). Also, the human economic activity can also increase the concentration of these metals in the sediment.

A comparison was made of the activity of individual gryphons in their passive and active phases. It was found that with an active gryphon, the output volume of spontaneous gases increases sharply (from 0.5 to $71 / \mathrm{min}$ ), and the temperature of the water-mud mixture increases (from $+10^{\circ} \mathrm{C}$ to $+16^{\circ} \mathrm{C}$ ) (Astakhov et al., 2001). The content of a number of chemical elements in mud breccias also changes (Astakhov et al., 2001; Sorochinskaya et al., 2008). During the activation of the Yu-9 and Yu-10 gryphons (samples Yu-9 / 17.08 and Yu-10 / 17.08), the contents of many elements such as $\mathrm{Fe}, \mathrm{Na}, \mathrm{Mg}, \mathrm{Mn}, \mathrm{Sc}, \mathrm{Rb}, \mathrm{As}, \mathrm{V}, \mathrm{Cr}$, $\mathrm{Co}, \mathrm{Ni}, \mathrm{Zn}, \mathrm{Zr}, \mathrm{Y}, \mathrm{Sn}, \mathrm{Cs}, \mathrm{W}, \mathrm{Pb}$ are decreased, while the contents of $\mathrm{Ba}, \mathrm{Li}, \mathrm{Na}$ are increased. A more contrasting feature is observed for the Yu-10 gryphon (Figure 5). Activation of gryphons is accompanied by a decrease in the content of REE, in the sample Yu-9/17.08, for example, from $111.25 \mathrm{~g} / \mathrm{t}$ decreasing to $110.45 \mathrm{~g} / \mathrm{t}$, and in the sample $\mathrm{Yu}-$ $10 / 17.08$, the content being from $109.71 \mathrm{~g} / \mathrm{t}$ decreasing to $59.83 \mathrm{~g} / \mathrm{t}$ (Figure 6). The most significant decrease is observed in the content of light lanthanides ( $\mathrm{La}$ and $\mathrm{Ce}$ ), where the ratio of LREE/HREE for gryphon Yu-10 during the activation is reduced from 4.89 to 3.91. The europium anomaly $\left(\mathrm{Eu} / \mathrm{Eu}^{*}\right)$ in the breccia is also reduced when the gryphon is activated, for example, for $\mathrm{Yu}-9$ gryphon from 0.62 to 0.59 , for $\mathrm{Yu}-10$ gryphon from 0.64 to 0.62 .

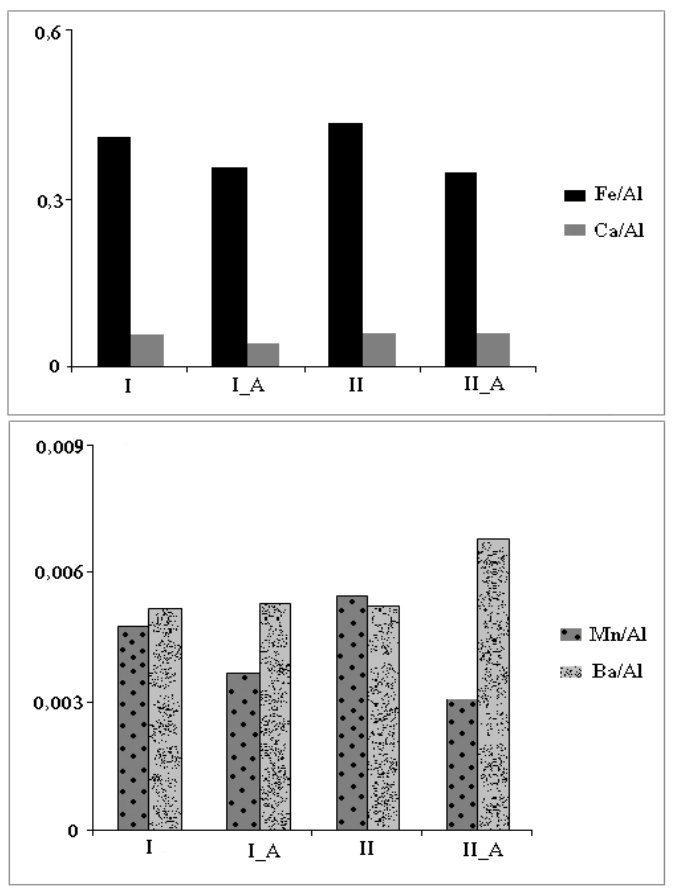

Figure 5. Changes in chemical compositions of mud volcanic breccia in active and passive eruptive mud; I, II- $\mathrm{Fe} / \mathrm{Al}, \mathrm{Ca} / \mathrm{Al}, \mathrm{Mn} / \mathrm{Al}, \mathrm{Ba} / \mathrm{Al}$ in samples selected from passive gryphons $\mathrm{Yu}-9$ and $\mathrm{Yu}-10$ respectively, I_A, II_A - Fe/Al, Ca/Al, Mn/Al, Ba/Al in samples selected with activation of gryphons (samples $\mathrm{Yu}-9 / 17.08$ and Yu-10/17.08)

Since YSMV refers to the carbonicmethane-type mud volcanoes, under activation, the rate of $\mathrm{CO}_{2}, \mathrm{CH}_{4}$ and $\mathrm{N}_{2}$ increases sharply (Shakirov, 2016). This promotes the formation and migration of soluble hydrocarbonate complexes of many elements, in particular iron, calcium, manganese and REE, etc. This is associated with a decrease in the content of these cations in the mud volcanic breccia during the activation of a gryphon. But an increase in the contents of a number of elements such as $\mathrm{Na}, \mathrm{Li}, \mathrm{Ba}, \mathrm{Hg}$, B, characterized by the mud breccia, is associated with endogenous supply along with the deep hydrocarbon gases (Aliyev et al., 2009; Shnyukov et al., 1992; Yakubov et al., 1980). 
Shakirov R.B., et al./Vietnam Journal of Earth Sciences 40 (2018)

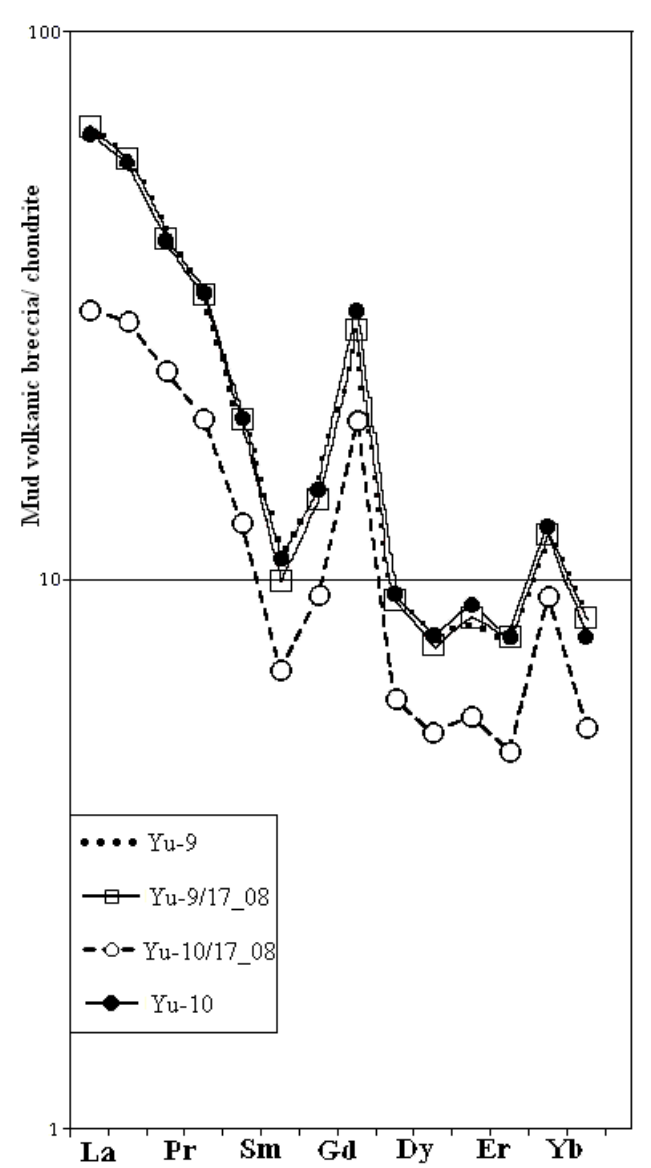

Figure 6. Rare earth element chondrite normalized of samples collected at active and passive gryphons of YSMV

\section{Conclusions}

The chemical and isotope compositions of free gases, and the chemical composition of the mud breccia including complex of authigenic minerals, indicate the genetic relationship of the Yuzhno-Sakhalinsky and Pugachevsky mud volcanoes. YSMV and PMV are located in the field of the sedimentary sequence (Bykovskaya suite), and are confined to one tectonic structure (Central-Sakhalin deep fault) and are of the carbonic-methanetype mud volcanoes. The carbon isotope composition of carbon dioxide $\left(\delta^{13} \mathrm{C}=-2.8\right.$ to $2.7 \%$ PDB $)$ and methane $\left(\delta^{13} \mathrm{C}=-27.1 \%\right.$
PDB) indicates the formation of these gases as a result of deep thermogenic transformation of organic matter. The contents of the most chemical elements in the mud breccia of YSMV and PMV are comparable to the Clarke contents of these elements (0.8-1.2 $\times \mathrm{C})$. For $\mathrm{Na}, \mathrm{Li}, \mathrm{Zn}, \mathrm{Sn}$, the $\mathrm{C}_{\text {sample }} /$ Clarke ratio varies from 1.4 to $5.2 \times \mathrm{C}$. Elevated contents of $\mathrm{Na}$ and $\mathrm{Li}$ are due to the ascending endogenous fluid.

The study of the chemical composition of the mud breccia during the change in the explosive activity of YSMV under the seismic activity allowed to clarify: when the gryphons are under activation against the background of an increase in the temperature of the water mud mixture and the volumes of spontaneous gases, the content of a number of elements (iron, calcium, manganese, rare earths, etc.) is decreased. This is explained by the formation of soluble hydrocarbonate complexes. When excess $\mathrm{CO}_{2}$ is removed, the above cations are precipitated from the solution in the form of iron - sideroplezite carbonates. The resulting carbonates are enriched with trace elements, which saturate the associated water during the activation period and inherit the carbon isotope composition of carbon dioxide.

For the Daginsky geothermal system, the main component of the spontaneous gas is methane having an isotopic composition of $\delta^{13} \mathrm{C}$ from -58.8 to $-57.0 \%$ PDB. This methane resulted from the mixture: a result of anaerobic decomposition of organic matter (thermogenic) and involving methane-forming bacteria (microbial). In such physicochemical conditions, the ferrous iron is bound to sulfides, and the main authigenic mineral on the DGHS is pyrite. Ooze samples from DGHS are depleted with trace elements compared to samples from YSMV and PMV, and $\mathrm{C}_{\text {sam- }}$ $\mathrm{ple} /$ Clarke values for the majority of the elements are $0.6 \times$ C. In DGHS ooze samples, only $\mathrm{Cd}(2.2-3.4 \times \mathrm{C})$ and $\mathrm{Pb}(0.7-1.5 \times \mathrm{C})$ are higher than the Clarke content. 
Vietnam Journal of Earth Sciences, 40(1), 56-69

Deep shears are the supply channels for both fluids from sedimentary basins (hydrocarbons) and magmatic rock fluids (helium, hydrogen, carbon dioxide). The mud volcanic gas emission from sedimentary basins is enhanced during seismic activity. The presence of active mud volcanoes and mineral springs proves the activity of deep faults, through which deep fluids migrate. The factors determining the 'weighting' of the methane carbon isotope composition in southern Sakhalin are probably the increased seismic activity of deep-seated faults, as well as the presence of intrusions and hydrothermally altered rocks.

Yuzno-Sakhalinsky and Pugachevsky mud volcanoes are sharply varied from the Daginskie gas-geothernal springs. This difference is related to the gasgeochemical zoning of the Sakhalin Island: mud volcanoes are located in the 'carbon dioxide-methane zone', while Daginskie gas-geothermal springs located in the 'methane zone'.

The same research pattern may be proposed to geothermal springs in Viet Nam along the Red River deep seated faults and geothermal-mud manifestations in the Central Vietnam.

\section{Acknowledgements}

Support by the Grant of the President of the Russian Federation for young scientists MK-2286.2017.5 and the RFBR grant No. 1805-00153 A is gratefully acknowledged.The work was conducted under partial financial support of the Far East Program FEB RASVAST (VAST 18-006) and the Vietnam Academy of Science and Technology VAST06.04/17-18.

\section{References}

Aliyev A.A., Guliyev I.S., Rakhmanov R.R., 2009. Catalog of eruptions of Azerbaijan mud volcanoes (1810-2007). Baku Nafta Press, 109p.

Astakhov A.S., et al., 2002. Defluitization process dynamic of the Central Sakhalin fault at seismic activi- zation (by monitoring results of the YuzhnoSakhalinsky mud volcano in July - August 2001) DAN 2002, 386(2), 223-228.

Decisions of operational interdepartmental regional stratigraphical meetings on the Paleogene and Neogene of east regions of Russia-Kamchatka, Koryak Upland, Sakhalin and Kuril Islands, 1998. An explanatory note to stratigraphical schemes. Responsible editor Gladenkov Y.B. Moscow GEOS, 147p.

Diatoms of the USSR Fossil and Recent. 1974. Leningrad Nauka, 1(1), 404p.

Dubinin A.V., 2006. Geochemistry of rare-earth elements in the ocean. Moscow Nauka, 360p.

Ershov V.V., Shakirov R.B., Obzhirov A.I., 2011. Isotope and geochemical characteristics of the YuzhnoSakhalinsky mud volcano free gases and their connection with regional seismicity. DAN, 440(2), 256-261.

Fedorov Y.N., et al., 2012. Crude oil microelement characteristic of Vogulkinsky and Tyumen basins oil and gas area: comparison. Lithosphere, 2, 141-151.

Geology of the USSR, 33. Sakhalin Island/Under the edited by Sidorenko A.V. Moscow Nedra, 1970, $464 \mathrm{p}$.

Grigoriev N. A., 2008. About clark content of chemical elements in the top part of continental crust. Lithosphere 1, 61-71. Thesis: 11.00.00. YuzhnoSakhalinsk, IMGG FEB RAS, 244p.

Hasle G.R., Syvertsen E.E., 1996. Marine diatoms. Identifying Marine Phytoplankton. San Diego, Academic Press, 5-385.

Horita J., 2001. Carbon isotope exchange in the system $\mathrm{CO} 2-\mathrm{CH} 4$ at elevated temperatures. Geochimica et Cosmochimica Acta, 65, 1907-1919.

Kholodov V.N., 2002. Mud volcanoes: distribution regularities and genesis. Lithology and Mineral Resources, 3, 227-22001.41.

Kopf A.J., 2002. Significance of mud volcanism. Rev. Geophysics, 40(2), 2-1-2-52.

Liu Chia-Chuan, et al., 2013. The geochemical characteristics of the mud liquids in the Wushanting and Hsiaokunshui Mud Volcano region in southern Taiwan: Implications of humic substances for binding and mobilization of arsenic. Journal of Geochemical Exploration, 128, 62-71. 
Shakirov R.B., et al./Vietnam Journal of Earth Sciences 40 (2018)

Lobodenko I.Y., 2010. Holocenic tectonic deformations (paleoseismo-dislocations) in zones of the Hokkaido-Sakhalin and Central Sakhalin faults. Candidate of geological and mineralogical science thesis. Moscow, 22p.

Melnikov O.A., 1987. Structure and geodynamics of the Hokkaido-Sakhalin folded region. Moscow Nauka, 93p.

Melnikov O.A., 2011. About dynamics and nature of Pugachevsky group the gaswaterclastic ("mud") volcanoes on Sakhalin according to visual observations and an orohydrography. Volcanology and Seismology, 6, 47-59.

Melnikov O.A., Ershov V.V., Kim Chong Un, etc., 2008. About the mud spring activity dynamic of the gaswaterclastic ("mud") volcanoes and its connection with seismicity on the example of the YuzhnoSakhalinsky volcano (Sakhalin Island). Pacific Geology 27(5), 25-41.

Melnikov O.A., Iliev A.Y., 1989. About new manifestations of mud volcanism on Sakhalin Island. Pacific geology, 3, 42-48.

Milkov, A.V., 2000. Worldwide distribution of submarine mud volcanoes and associated gas hydrates. Marine Geology, 167, 29-42.

Oreshkin V.N., Gordeev V.V., 1983. Geochemistry of cadmium and plumbum (lead) in suspension of the rivers of Black, Azov and Caspian Sea areas. Geochemistry, 4, 603-613.

Petelin V.P., 1957. Mineralogy of sand-aleurite fractions in the Sea of Okhotsk marine sediments. Proceedings of Oceanology Institute of USSR Academy of Sciences, XXII.

Prasolov E.M., 1990. Isotope geochemistry and origin of natural gases. St. Petersburg: Nedra, 283p.

Shakirov R.B., 2016. Gasgeochemical fields of the marginal seas on the Far Eastern Region: distribution, origin, relations to the geological structures, gashydrates and seismo-tectonics. Dissertation of Doctor of Geological and Mineralogical Sciences (Dr.Sci.). POI FEB RAS, Vladivostok 459p. (In Russian)

Shakirov R.B., Syrbu N.C., Obzhirov A.I., 2012. Isotope and gas-geochemical features of methane and carbon dioxide distribution on Sakhalin Island and adjacent shelf of the Okhotsk Sea. Bulletin of KRAESC Earth Sciences, 2(20), 100-113.

Shnyukov E.V., et al., 1992. Mud volcanism of the Kerch and Tamansky region. Kiev, Naukova dumka, 200 p.

Siryk I.M., 1968. Oil and gas content of the east slopes of the West Sakhalin mountains. Moscow: Nauka, 8-14.

Sorochinskaya A.V., et al., 2008. Geochemical and mineralogical features of mud volcanoes of Sakhalin Island. Bulletin of FEB RAS, 4, 58-65.

VeselovO.V., Soinov V.V., 1997. Tektonosphere geodynamics of conjunction zone of the Pacific Ocean with Eurasia. Yuzhno-Sakhalinsk: IMGG FEB RAS, 4,153-176.

Veselov O.V., Volgin P.F., Lutaya L.M., 2012. Structure of the Pugachevsky mud-volcano sedimentary cover (Sakhalin Island) by geophysical modeling data. Pacific Geology, 31(6), 4-15.

Vinogradov A.P., 1962. Average contents of chemical elements in the main types the igneous rocks. Geochemistry, 7, 555-571.

Yakubov A.A., et al., 1980. Mud volcanism of the Soviet Union and its connection with oil-and-gas content. Baku, 165p.

Zharov A.E., Mitrofanova L.I., Tuzov V.P., 2013. Stratigraphy of Cainozoic sediments of the Northern Sakhalin shelf. Stratigraphy, Geological correlation 21(5), 72-93. 